ACTA UNIVERSITATIS LODZIENSIS

FOLIA LITTERARIA POLONICA 1(47) 2018

http://dx.doi.org/10.18778/1505-9057.47.10

Katarzyna Taczyńska*

\title{
A dokąd teraz? Problematyka obozowa w perspektywie jugosłowiańskiej. Przypadek Elviry Kohn ${ }^{1}$
}

\section{Wprowadzenie}

Obóz koncentracyjny jako element rzeczywistości Jugosławii i państw powstałych po jej rozpadzie powracał w dwudziestowiecznej historii tego regionu co najmniej kilka razy. Szczególnymi momentami w przeszłości, w których obóz odgrywał strategiczne ogniwo, były czas drugiej wojny światowej, następnie rozrachunków wewnętrznych po wykluczeniu Jugosławii z Kominformu w 1948 r. i najbliższy nam czasowo okres wojny domowej w latach 90. XX w. Choć wyliczanie nazw obozów w tym miejscu, ze względu na liczbę i różną specyfikę, może budzić zastrzeżenia, warto przywołać choć te najważniejsze czy najbardziej rozpoznawalne, by wskazać, a tym samym zaakcentować newralgiczne miejsca z przeszłości Jugosławii, do dziś odgrywające istotną (choć nierzadko upolitycznioną i kontrowersyjną) rolę $\mathrm{w}$ debacie publicznej².

W przypadku drugiej wojny światowej obóz wydaje się stanowić nieodłączny, z dzisiejszej perspektywy oczywisty fragment, jak pisał Martin Pollack,

* Dr, adiunkt - stażysta podoktorski, Uniwersytet im. Adama Mickiewicza w Poznaniu, Instytut Filologii Słowiańskiej, Pracownia Genderowych i Transkulturowych Studiów Bałkanistycznych; ul. Aleksandra Fredry 10, 61-701 Poznań; kattac@amu.edu.pl.

${ }^{1}$ Praca powstała w wyniku realizacji projektu badawczego o $\mathrm{nr}$ 2015/16/S/HS2/00092 finansowanego ze środków Narodowego Centrum Nauki.

${ }^{2}$ Niektóre miejsca pamięci (Jasenovac, Bleiburg, Vukovar) obecne w debacie publicznej w Chorwacji zostały szczegółowo omówione za pomocą analizy dyskursu w artykule: M. Falski, T. Rawski, Jasenovac, Bleiburg, Vukovar: miejsca pamięci a dyskurs publiczny, w: Obóz - muzeum. Trauma we współczesnym wystawiennictwie, red. M. Fabiszak, M. Owsiński, Universitas, Kraków 2013, s. 193-214. Ciekawym projektem, którego autorka upomina się o pamięć zapomnianych miejsc tragedii na terenie Chorwacji, jest cykl fotograficzny Neplodna tla (Nieurodzajne ziemie) Sandry Vitaljić z 2016 r. Sfotografowane przez artystkę ,jałowe ziemie” w symboliczny sposób mają przypominać o tym, że tereny te stanowią nieustannie „płodny obszar” manipulacji politycznej. Zob. też inspirowany dziełem artystki esej Renaty Jambrešić-Kirin Med iz Jasenovca (Miód z Jasenovaca), zob. taż, Med iz Jasenovca, w: tejże, Korice od kamfora, Meandarmedia, Zagreb 2015, s. 135. 
„skażonego krajobrazu”3 Jugosławii. Wspomnieć należy tutaj o obozie w miejscowości Jasenovac (na pograniczu dzisiejszych Chorwacji i Bośni), działającym w latach 1941-1945, który jako kompleks wraz z mniejszymi podobozami został utworzony przez chorwacką faszystowską organizację ustaszów w Niezależnym Państwie Chorwackim (Nezavisna Država Hrvatska, NDH), podporządkowanym III Rzeszy. Celem istnienia obozu była eksterminacja ludności serbskiej, żydowskiej oraz Romów. Wśród osadzonych byli obecni również chorwaccy więźniowie polityczni ${ }^{4}$. Szczególne miejsce na mapie pamięci o Holokauście zajmuje również istniejący na terenie Belgradu (w dzielnicy Zemun, która należała do terytorium NDH) obóz koncentracyjny Sajmište (Judenlager Semlin) $)^{5}$ Prymarnym zadaniem tego obozu była likwidacja więźniów pochodzenia żydowskiego, głównie kobiet, dzieci i osób starszych, w samochodach śmierci ${ }^{6}$. Trzeba przypomnieć jednak, że Królestwo Jugosławii, w następstwie kapitulacji armii i ucieczki króla, zostało podzielone pomiędzy niemieckich i włoskich zwycięzców na dwie strefy wpływów? ${ }^{7}$ W przypadku Chorwacji, która w niniejszym tekście interesować nas będzie najbardziej, rozczłonkowanie kraju oznaczało z jednej strony utwo-

${ }^{3}$ Zob. M. Pollack, Skażone krajobrazy, przekł. K. Niedenthal, Wydawnictwo Czarne, Wołowiec 2014.

${ }^{4}$ Informacje o Jasenovacu odnaleźć można na stronie działającego dziś w tym miejscu muzeum - Spomen područje Jasenovac [Miejsce Pamięci Jasenovac]), zob. www.jusp-jasenovac.hr/ Default.aspx?sid=5021 [dostęp: 28.02.2017]. Więcej o historii obozu zob. N. Mataušić, Jasenovac 1941.-1945. Logor smrti i radni logor, Javna ustanova Spomen-područje Jasenovac, Naklada Jesenski i Turk, Jasenovac-Zagreb 2003; na temat przemian dyskursu o obozie i towarzyszących temu trudnościach zob. S. Goldstein, Jasenovac - tragika, mitomanija, istina, Fraktura, Zaprešić 2016.

${ }^{5}$ Obóz Sajmište był administrowany przez władze niemieckie, ale do dziś pozostaje nierozwiązana i dyskutowana przez historyków kwestia udziału w tragedii Żydów kolaborującego rządu serbskiego, w tym przede wszystkim stojących na jego czele najpierw Milana Aćimovicia, a następnie gen. Milana Nedicia. Zob np. dyskusję na ten temat dwóch, reprezentujących odrębne stanowiska, serbskich historyków, Milana Ristovicia i Bojana Dimitrijevicia, z dnia 8.12.2015 (program Pressing), https://www.youtube.com/watch?v=jjT3GFYfh4M [dostęp: 28.02.2017].

${ }^{6}$ Na temat historii obozu zob. M. Koljanin, Nemački logor na Beogradskom Sajmištu 1941-1944, Institut za savremenu istoriju, Beograd 1992; J. Bajford [Byford], Staro sajmište. Mesto sećanja, zaborava i sporenja, Beogradski centar za ljudska prava, Beograd 2011. Podstawowe informacje o obozie znaleźć można na prowadzonej przez Jovana Byforda stronie internetowej: http://www. semlin.info/, powstałej jako wynik projektu finansowanego przez British Academy. Zob. też prace analizujące polityczną marginalizację obozu Sajmište w czasach socjalistycznej Jugosławii i jego późniejszą instrumentalizację, np. O. Manojlović Pintar, A. Ignjatović, Prostori selektovanih memorija: Staro sajmište u Beogradu i sećanje na Drugi svetski rat, w: Kultura sjećanja: 1941, red. S. Bosto, T. Cipek, O. Milosavljević, Disput, Zagreb 2008, s. 95-112; M. Ivanković, The „, Sajmište” (Exhibition Grounds) in Semlin, Serbia: The Changing of Memory, „Jewish Political Studies Review" 2010, t. 22, nr 3-4, s. 59-67; H. Karge, Sajmište, Jasenovac, and the Social Frames of Remembering and Forgetting, „Filozofija i društvo” 2012, nr 4, s. 106-118.

${ }^{7}$ Szczegóły podziału w poszczególnych krajach można prześledzić w: B. Jelavich, Historia Bałkanów. Wiek XX, przekł. M. Chojnacki, J. Hunia, Wydawnictwo Uniwersytetu Jagiellońskiego, Kraków 2005, s. 275-278. 
rzenie NDH, podlegającego częściowo niemieckiej, częściowo włoskiej władzy, z drugiej zaś znaczną utratę części wybrzeża dalmatyńskiego na rzecz Włochów. $\mathrm{Na}$ administrowanej przez Włochy wyspie Rab w lipcu 1942 r. został utworzony obóz Kampor, którego więźniarką była bohaterka tego tekstu - Żydówka Elvira Kohn (1914-2003). Obóz istniał do 8 września 1943 r. - do czasu kapitulacji Włoch. Celem istnienia włoskich obozów koncentracyjnych była przede wszystkim izolacja (nie likwidacja) Żydów ${ }^{8}$.

Wśród obozów i więzień istniejących w socjalistycznej Jugosławii wymienić należy przede wszystkim utworzony w 1949 r. na kamienistej wyspie Goli otok (Naga Wyspa) dla adwersarzy istotnego kroku poczynionego przez Komunistyczną Partię Jugosławii (KPJ). Wewnętrzna sytuacja w państwie była następstwem konfliktu pomiędzy Jugosławią a ZSRR. Kominformowców, czyli opozycję antytitowską popierającą stanowisko Moskwy o konieczności podporządkowania się Jugosławii Kremlowi, uznano za głównych wrogów wewnętrznych. Dla przeciwników decyzji KPJ zostały utworzone instytucje poprawcze, w których zamykano faktycznych, ale też domniemanych przeciwników9. Goli otok, jako największy z nich, uznaje się za symbol wszystkich ośrodków, w których osadzano za działalność prokominformowską. We wspomnieniach byłych więźniów, publikowanych dopiero po śmierci Josipa Broza Tity w 1980 r., realia obozów porównywano do rzeczywistości panującej w radzieckim gułagu i w nazistowskich obozach koncentracyjnych ${ }^{10}$.

Obóz jako narzędzie opresji oraz kluczowa metafora opisu rzeczywistości powrócił w Jugosławii w czasie wojny domowej. Z jednej strony obóz stanowił ponownie realnie istniejące miejsce stworzone w celu koncentracji osób określonej przynależności etnicznej. W Bośni i Hercegowinie były to utworzone przez bośniackich Serbów w 1992 r. obozy, m.in. Keraterm (w pobliżu Prijedoru) i Omarska (w miejscowości o tej samej nazwie), w których przetrzymywano i torturowano bośniackich cywilów, Muzułmanów i Chorwatów. Z drugiej strony, w dyskursie literackim i naukowym, poza tworzeniem bezpośrednich

${ }^{8}$ D. Kečkemet, Židovski sabirni logori na području pod talijanskom okupacijom, w: Antisemitizam, Holokaust, Antifašizam, red. I. Goldstein, Židovska općina Zagreb, Zagreb 1996, s. 120. Na temat historii obozu zob. I. Kovačić, Kampor 1942-1943: Hrvati, Slovenci i Židovi u koncentracijskom logoru Kampor na otoku Rabu, Adamić, Rijeka 1998.

${ }^{9}$ Przyczyny sporu, historia powstania obozu Goli otok oraz proces kształtowania historycznego i literackiego dyskursu zostały szczegółowo omówione w: K. Taczyńska, „Dowcip trwajacy dwa i pót roku”. Obraz Nagiej Wyspy w serbskim dyskursie literackim i historycznym końca XX i początku XXI wieku, Wydawnictwo DiG, Edition La Rama, Warszawa-Bellerive-sur-Allier 2016.

${ }^{10}$ Zob. nр. Д. Михаиловић, На трагу гулага и холокауста, w: tegoż, Кратка историја caтирања, Завод за уџбенике и наставна средства, Београд 2005, s. 79-82; Ženski logor na Golom otoku. Ispovesti kažnjenica i islednice, red. D. Simić, B. Trifunović, ABC Product, Beo$\operatorname{grad} 1990$, s. 213. 
paraleli do konfliktów narodów z przeszłości, pojawiały się również obrazowe porównania nawiązujące do rzeczywistości obozowej poprzez tworzenie analogii do drugiej wojny światowej i Zagłady. Serbska pisarka Marija Knežević w eseju Obóz jako metafora pisała, przytaczając słowa przyjaciółki, że życie w regionie Bałkanów (odizolowanym od reszty świata) w czasie wojny można by porównać do przebywania w obozie opasanym niewidocznym drutem kolczastym, do „abstrakcyjnego poczucia obozowej niewoli”, w którym ,pozwolono ci na ruch tylko w zamkniętym kole" ${ }^{\prime 1}$. Natomiast David Bruce MacDonald, analizując trwającą wówczas w Jugosławii wojnę medialną i dominujący w dyskursie nacjonalistyczny język propagandy, zadawał czytelnikowi już w tytule swojej książki prowokacyjne pytanie o istnienie bałkańskich holokaustów ${ }^{12}$.

Celem powyższego zestawienia nie jest bynajmniej zrównanie w jednym szeregu dramatycznych wydarzeń, w których obóz wykorzystywany był jako narzędzie represji. Chodziło przede wszystkim o wyróżnienie faktów koniecznych do wskazania, w jakich dwudziestowiecznych kontekstach historyczno-politycznych w przypadku Jugosławii można mówić o kategorii 'obozu'. Choć jednocześnie zaznaczyć należy, że przedstawiony przegląd stanowi zaledwie zarys i nie wyczerpuje opisu obozowej charakterystyki regionu. W każdym z podanych przypadków, co warto podkreślić, punktem odniesienia dla analizy (co bywa również polem nadużyć) zarówno ze strony uczestników, świadków jak i badaczy, niezwykle często staje się dziedzictwo drugiej wojny światowej. Dlatego potrzeba jasnej systematyzacji i rzetelnych badań związanych z tym okresem - to ciągle jedno z najważniejszych zadań stojących przede wszystkim przed historykami i historykami literatury. Upominanie się o obowiązek pogłębionej refleksji oraz walkę z niewiedzą czy wręcz amnezją społeczną nieustannie powraca ze strony środowiska akademickiego oraz pisarzy ${ }^{13}$. Natomiast obszarem badań, w którym dostrzec można znaczące braki, pozostaje historia kobiet, niewystarczająco przebadana i tylko w niewielkim stopniu uwzględniania w edukacji historycznej. Trafnie na ten temat pisze, podążając tropem Joan Wallach Scott, Sandra Prlenda, która akcentuje, że włączenie historii kobiet do narracji historycznej nie może polegać na zamieszczeniu na końcu lekcji krótkiej notki o udziale kobiet i dzieci, lecz chociaż częściowo powinna stanowić podstawę analizy głównych wydarzeń społecznej,

${ }^{11}$ M. Knežević, Obóz jako metafora, przeł. D.J. Ćirlić „Tygiel Kultury” 1997, nr 10-12, s. 16, 18.

${ }^{12}$ Zob. D.B. MacDonald, Balkan holocausts? Serbian and Croatian victim-centred propaganda and the war in Yugoslavia, Manchester University Press, Manchester and Chicago 2002.

${ }^{13}$ Zob. np. artykuł Gabi Abramac pod znaczącym tytułem Holocaust Revisionism in Croatia: How Anne Frank Became Persona Non Grata, „The Algemeiner” 31.01.2017 [online], https://www. algemeiner.com/2017/01/31/holocaust-revisionism-in-croatia-how-anne-frank-became-persona-non-grata/ [dostęp: 28.02.2017]. Zob. też A. Barbir-Mladinović, O holokaustu iz književne perspektive, „Radio Slobodna Evropa” 12.09.2009 [online], http://www.slobodnaevropa.org/a/holokaust/1820982.html [dostęp: 28.02.2017]. 
politycznej, ekonomicznej i kulturowej historii ${ }^{14}$. Pomimo że, jak słusznie zwraca uwagę Natka Badurina, w Chorwacji szczególnie po 2000 r. perspektywa kobiet staje się wyraźnie obecna $\mathrm{w}$ badaniach historycznych ${ }^{15}$, dzieje roli kobiet $\mathrm{w}$ przeszłości nadal stanowią wyzwanie dla współczesnych rozważań humanistycznych. Celem zasadniczym jest bowiem przekształcenie bezspornego udziału kobiet w przeszłości (chorw. povijest, niem. Geschichte) w rzeczywisty udział w historii jako dyscyplinie (chorw. historija, niem. Historie) ${ }^{16}$. Bardzo ważnym elementem tego procesu, na co szczególny nacisk kładzie Renata Jambrešić-Kirin, jest „kontrapunktowanie różnorodnych kobiecych głosów”, poprzez uwzględnienie w badaniach historii prywatnych, które przeczą homogeniczności kobiecych ról w przeszłości ${ }^{17}$. Tak szeroko zakrojony wstęp, mam nadzieję, umożliwi w dalszej kolejności przedstawienie losów i łatwiejsze zrozumienie (nie)obecności Elviry Kohn i pozostawionych przez nią świadectw w chorwackim dyskursie historycznym. W niniejszym tekście chciałabym poprzez analizę dokumentów osobistych ${ }^{18}$ i fotografii autorstwa Kohn zastanowić się, jaką wartość poznawczą niosą one ze sobą, oraz uchwycić wyłaniającą się z nich specyfikę narracji na temat drugiej wojny światowej i doświadczenia Żydów w Jugosławii.

\section{Żydówki w historiografii byłej Jugosławii}

Historia obecności Żydów w Jugosławii ma złożoną strukturę. Jednym z kluczowych aspektów wyróżniających tę grupę w regionie jest społeczność Sefardyjczyków, która po wygnaniu z Półwyspu Iberyjskiego osiedliła się w XVI w. na

${ }^{14}$ S. Prlenda, Ženska povijest i sjećanje na Drugi svjetski rat, w: Sjećanja žena žrtava nacizma i nedemokratskih režima, red. S. Prlenda, Centar za ženske studije, Zagreb 2009, s. 11-12.

${ }^{15}$ N. Badurina, Proučavanje holokausta iz ženske perspektive, w: Sjećanja žena..., s. 40. Zob. też artykuł Nataliji Rumenjak, która omawia powstanie w 2000 r. stałej sekcji Povijest žena (Historia kobiet) przy Kongresie Historyków Chorwackich oraz treść poszczególnych wystąpień, taż, Povijest žena u hrvatskoj historiografiji, „Otium” 1999-2000, nr 7-8, s. 27-29. Przeglądu pierwszych opracowań na temat historii kobiet w Chorwacji zgodnie z systematyzacją Gerdy Lerner dokonuje Andrea Feldman, zob. taż, Poslednjih tisuću godina: povijest žena - ženska povijest - kulturna povijest, „Otium” 1999-2000, nr 7-8, s. 30-37. Zdaniem Feldman historia kobiet w Chorwacji jako temat badawczy zaczęła pojawiać się od początku lat. 80. ubiegłego wieku, zob. taż, Predgovor, w: Žene u Hrvatskoj. Ženska i kulturna povijest, red. tejże, Institut „Vlado Gotovac", Ženska infoteka, Zagreb 2004, s. 16.

${ }^{16}$ Đ. Knežević, Žene u povijesti - historija bez žena, w: Seminar ,Žene i politika: žene u povijesti/ historija bez žena”. Dokumentacija, red. Đ. Knežević, K. Dilić, Ženska infoteka, Zagreb 2001, s. 9.

${ }^{17}$ R. Jambrešić-Kirin, Prilozi za ratnu povijest iz rodne perspektive, „Otium” 1999-2000, nr 7-8, s. 83-84.

18 J. Leociak, Tekst wobec Zagłady (o relacjach z getta warszawskiego), Fundacja na Rzecz Nauki Polskiej, Leopoldinum, Wrocław 1997, s. 15. 
Bałkanach ${ }^{19}$. Mniejszość ta, obok społeczności Żydów aszkenazyjskich, stanowiła ważny element bałkańskiej rzeczywistości kulturowej. Wielowymiarowość kultury żydowskiej dodatkowo rozszerza się, gdy uwaga zostanie skierowana w stronę kobiet. Harriet Freidenreich zauważa, że w słabo rozpoznanej kobiecej historii Bałkanów przeszłość Żydówek przedstawia jej jeszcze mniej znane ogniwo ${ }^{20}$. Uzupełnieniem tego stwierdzenia są słowa Diny Katan Ben Zion, która wskazuje, że choć początków żydowskiej literatury kobiet w krajach byłej Jugosławii upatrywać należy w twórczości dwóch urodzonych w tym samym, 1891 roku pisarek - Laury Papo Bohorety oraz Pauliny Lebl Albali, to jednak w obu przypadkach rękopisy autorek ukazały się dopiero w 2005 r. - są to odpowiednio: Sefardska žena u Bosni (Sefardyjka w Bośni) i Tako je nekad bilo (Tak było kiedyś $)^{21}$. Trudność w kompletowaniu tekstów źródłowych stanowi bowiem nieobecność w powszechnym obiegu wielu tekstów o charakterze wspomnieniowym autorstwa kobiet. Nie powinno więc dziwić, że niezwykle ważną rolę w ich odkrywaniu i określaniu sposobów funkcjonowania w środowisku literackim odgrywają badania archiwalne, prowadzone nie tylko w oficjalnych zbiorach narodowych, ale również z uwzględnieniem dokumentacji prywatnej. Etap zbierania, systematyzowania i archiwizowania tekstów źródłowych ze względu na ich rozproszenie i marginalizację jest więc czasochłonny i wymaga szeroko zakrojonej kwerendy. Dzięki temu na przykład udało się odnaleźć dwa dzienniki pisane w czasie drugiej wojny światowej przez mieszane aszkenazyjsko-sefardyjskie małżeństwo Ervina Salcbergera oraz Lei Abinum. Oboje autorzy brali aktywny udział w ruchu partyzanckim. Ich świadectwa, zestawione obok siebie z komentarzem historycznym, ukazały się w roku 201322. Jednak zdarza się również, że nawet opublikowany tekst może wiele lat czekać na właściwe odczytanie i redefinicję wartości, jak miało to miejsce w przypadku zapomnianego Dnevnika jedne Judite (Dziennika pewnej Judyty) Ženi Lebl z 1990 r., w którym autorka - wcielając się w rolę swojej matki, zgładzonej w obozie Sajmište - zapisuje obserwacje z czasów okupacji Belgradu w 1941 roku $^{23}$. Niezwykle cenne

${ }^{19}$ Zob. J. Večerina Tomaić, Bohoreta - najstarija kći, Židovska vjerska zajednica Bet Israel, Zagreb 2016; A. Twardowska, La mužer sefardi de Bosna. Literacka i kulturalna działalność Laury Papo-Bohorety, w: Poznać Bałkany. Historia - Polityka - Kultura, red. K. Taczyńska, S. Sochacki, M. Zečević, Interdyscyplinarne Koło Naukowe Doktorantów, Toruń 2011, s. 205-213.

${ }^{20}$ H. Freidenreich, Yugoslavia, ,Jewish Women's Archive” [online], https://jwa.org/encyclopedia/article/yugoslavia [dostęp: 28.02.2017].

${ }^{21}$ D. Katan Ben Zion, The Feminine Voyage in the post Holocaust Jewish Literature in Former Yugoslavia, „Interkulturalnost” 2014, nr 7, s. 188.

${ }_{22}$ Zob. D. Šarenac, I. Pantelić, Dve polovine sećanja. Partizanski dnevnici kao izvor za istoriju Drugog svetskog rata, Institut za savremenu istoriju, Beograd 2013.

${ }^{23} \mathrm{Na}$ temat Dnevnika jedne Judite zob. K. Taczyńska, Pamięć matki - pamięć o matce. O „Dzienniku pewnej Judyty” Ženi Lebl, „Miscellanea Posttotalitariana Wratislaviensia” 2017, 
okazały się również opublikowane przez Jašę Almulego w 2005 r. cztery listy napisane przez Hildę Dajč, dziewiętnastoletnią więźniarkę i ofiarę obozu Sajmište. Młodej kobiecie dzięki pracy w obozowym szpitalu udało się przesłać krótkie listy do dwóch swoich przyjaciółek ${ }^{24}$. Bywa jednak również tak, że gromadzona $\mathrm{w}$ archiwach dokumentacja $\mathrm{w}$ formie listów i/czy dzienników do dziś nie doczekała się publikacji lub jako zbiór fragmentów wspomnień pozostaje nieodczytana ${ }^{25}$. Autorki tych tekstów jako ,anonimowi świadkowie historii” stają się - posługując się frazą Julijany Matanović przypomnianą przez Magdalenę Dyras - „świadkami słabymi”, których imion próżno szukać w encyklopediach czy leksykonach: „Przechodzą przez życie niezauważeni, a o ich losach świadczą jedynie wyblakłe fotografie, prywatne listy i rodzinne pamiątki" ${ }^{26}$. Dokumenty osobiste Żydówek, ze względu na swoją kulturową wielowarstwowość, podlegają (nie zawsze zamierzonemu) społecznemu wykluczeniu, stając się ,niewidzialnymi świadectwami”, o których pisała Aleksandra Ubertowska ${ }^{27}$.

nr 6: Trauma jako kulturowy palimpsest: (post)komunizm w kontekście porównawczym nowoczesności, totalitaryzmów i (post)kolonializmów, red. D. Kołodziejczyk, B. Stefanescu, M. Świetlicki, s. 217-231; taż, ,, A Scattered Mosaic of Records and Reminiscences”: Ženi Lebl's War Odyssey in Her Personal Writings, w: An Introspective Approach to Women's Intercultural Fieldwork, red. U. Markowska-Manista, J. Pilarska, Wydawnictwo Akademii Pedagogiki Specjalnej im. M. Grzegorzewskiej, Warszawa 2017, s. 68-102. Ženi Lebl jest ponadto autorką prozy wspomnieniowej Ljubičica bela. Vic dug dve i po godine (Biały fiołek. Dowcip trwający dwa i pót roku) z 1990 r., dokumentującej pobyt autorki m.in. w więzieniu Glavnjača oraz obozach Sveti Grgur i Goli otok w latach 1949-1951.

${ }^{24}$ Listy najpierw zostały opublikowane w książce Jevrejke govore (Żydówki mówią) w 2005 r., a następnie wraz z opisami rozmów z odnalezionymi w 1989 r. przez Jašę Almulego przyjaciółkami Hildy Dajč - Nadi Novak i Mirjaną Petrović, które były adresatkami listów, w: J. Алмули, Страдање и спасавање српских Јевреја, Завод за уџбенике, Београд 2010, s. 33-54. Są też dostępne na wspomnianej stronie internetowej na temat obozu Sajmište, zob. https://www.open. ac.uk/socialsciences/semlin/sr/hilda-dajc.php [dostęp: 28.02.2017].

${ }^{25}$ Wiele tekstów kobiet mających formę rękopisu wciąż czeka na wydobycie z archiwalnego niebytu. Wspomnieć można w tym miejscu zapisany w języku chorwackim dziennik (175 stron) Milojki Mezorany, który powstawał w roku 1943 r. (wcześniejsze zapiski z 1941 i 1942 zostały przez autorkę zniszczone) i był kontynuowany po powrocie autorki z obozu Auschwitz, do którego trafiła w 1944 r. Na temat dziennika zob. M. Sobolevski, Dnevnik Milojke Mezorane - sušačke Anne Frank, „Sveti Vid” 2006, nr 11, s. 151-188; N. Badurina, Ženska svjedočenja iz koncentracijskih logora, w: tejże, Nezakonite kćeri Ilirije, Centar za ženske studije, Zagreb 2009, s. 219-243. Nieskomentowana pozostaje skromna korespondencja Luciji Sellan (Selan) z obozu Auschwitz z 1944 r. zapisana w języku niemieckim gotyckim pismem odręcznym Sütterlinschrift.

${ }^{26}$ M. Dyras, Re-inkarnacje narodu. Chorwackie narracje tożsamościowe w latach dziewięćdziesiatych XX wieku, Wydawnictwo Uniwersytetu Jagiellońskiego, Kraków 2009, s. 144.

27 A. Ubertowska, ,Niewidzialne świadectwa”. Perspektywa feministyczna w badaniach nad literatura Holokaustu, „Teksty Drugie” 2009, nr 4, s. 214-226. 


\section{Elvira Kohn - kobieta i wojna}

Elvira Kohn nie jest postacią nieznaną w historii Jugosławii czy Chorwacji ${ }^{28}$. Odnalezienie informacji, rozproszonych różnego rodzaju fragmentów opisujących jej życie lub dorobek w zakresie fotografii, jeśli badacz wykaże się odrobiną determinacji, może zakończyć się sukcesem. Większość z tych odłamków polifonicznej mozaiki o Kohn to na ogół skromne notatki lub materiały przedstawiające wybrane aspekty jej życia lub działalności, przede wszystkim fotografii. Kohn po zakończeniu wojny prowadziła dział fotograficzny Jugosłowiańskiej Armii Ludowej (fotosekcija Doma JNA). Po przejściu na emeryturę w 1964 r. wiodła spokojne życie, zmarła w 2003 r. (Kohn została pochowana na cmentarzu Mirogoj w Zagrzebiu). Wydarzeniem, które przypomniało oraz w pewien ważny i potrzebny sposób odświeżyło osiągnięcia fotografki była retrospektywna wystawa (około czterdziestu zdjęć) przygotowana przez Rheę Ivanuš w Galerii Gminy Żydowskiej w Zagrzebiu w 1997 r. na podstawie fotografii i negatywów, które Kohn przekazała do archiwum Muzeum Historycznego Chorwacji (Hrvatski povijesni muzej) ${ }^{29}$. Prezentacja ta na nowo obudziła zainteresowanie zdjęciami Kohn i zaowocowała szerszą i pogłębioną refleksją nad jej fotograficzną twórczością. Wymienić w tym miejscu należy przede wszystkim opracowanie Branki Hlevnjak Fotografkinje. Prilozi povijesti hrvatske fotografije 1870-2000 (Fotografki. Przyczynki do historii chorwackiej fotografii 1870-2000) z 2005 r., w którym autorka drobiazgowo analizuje w sposób chronologiczny i tematyczny przemiany w chorwackiej fotografii przez pryzmat obrazów tworzonych przez kobiety. Elvira Kohn jest bohaterką jednego z rozdziałów, zatytułowanego Ratna fotografija (Wojenna fotografia) ${ }^{30}$. Postać fotografki zainspirowała również zespół badaczy projektu Centropa, tworzących bazę danych

${ }^{28}$ Niestety, postać Elviry Kohn nie pojawia się w wydanym w 2016 r. w Zagrzebiu leksykonie przedstawiającym sylwetki wybitnych kobiet w Chorwacji (Naše žene. Leksikon znamenitih žena Hrvatske od X. do XX. stoljeća, red. L. Boršić, I. Skuhala Karasman).

${ }^{29}$ Zob. katalog z wystawy R. Ivanuš, Fotografije: Elvira Kohn. Retrospektiva, Galerija „Milan i Ivo Steiner", Zagreb 1997. Warto zwrócić uwagę, że za graficzne opracowanie katalogu odpowiadał Alfred Pal, dziennikarz i malarz żydowskiego pochodzenia, który w czasie drugiej wojny światowej był więźniem obozu koncentracyjnego na wyspie Rab, a w czasach Jugosławii Tity został osadzony na wyspie Goli otok. Zob. np. K. Taczyńska, Dowcip..., s. 226-228, 232-237.

${ }^{30}$ B. Hlevnjak, Fotografkinje. Prilozi povijesti hrvatske fotografije 1870-2000., Društvo povjesničara umjetnosti Hrvatske Zagreb, Design Art, Zagreb 2005, s. 74-79. Zob. też opracowanie Hlevnjak i Ivanuš Hrvatska antiratna fotografija: Prvi svjetski, Drugi svjetski i Domovinski rat (Udruga za promicanje oblikovanja i umjetnosti, Design Art, Centar za kuluru i obrazovanje, Zagreb 2008), w którym informacje na temat Kohn są w znacznej mierze powtórzeniem informacji zamieszczonych we wcześniejszych publikacjach autorek, mimo to w nowym kontekście nabierają nieco innych, ciekawych znaczeń kulturowych. Zob. też B. Blasin, I. Marković, Ženski vodič kroz Zagreb, Meandar, Zagreb 2006, s. 202-211; Zanimljive žene: Elvira Kohn, „Makabijada" [online], http://www.makabijada.com/dopis/elvirakon.htm [dostęp 28.02.2017]. 
pamięci żydowskiej z terenów Centralnej i Wschodniej Europy, byłego ZSRR oraz społeczności sefardyjskiej z Grecji, Turcji i Bałkanów ${ }^{31}$, do przeprowadzenia z nią wywiadu biograficznego, który został zrealizowany w maju 2003 r., kilka miesięcy przed jej śmiercią, przez Leę Šiljak ${ }^{32}$. Tymczasem dotychczas bardzo niewiele uwagi poświęcono zapiskom prowadzonym przez Kohn podczas pobytu w obozie na wyspie Rab. Są to: pisany przez Kohn w 1943 r. dziennik, wiersz oraz list wysłany z obozu do przyjaciółki w Zagrzebiu - Danicy Balen ${ }^{33}$. Żaden z tych tekstów dotychczas nie został opublikowany. Jedynym artykułem, poza jednozdaniowymi informacjami na temat aktu pisania dziennika ${ }^{34}$, który zajmuje się w całości prezentacją zapisków Kohn, jest praca Luciji Benyovsky z 1996 r., omawiająca ich strukturę i okoliczności powstania. W swojej analizie chciałabym przyjrzeć się z jednej strony fotograficznym, z drugiej - tekstowym śladom upamiętniającym przeszłość Kohn, by móc udzielić odpowiedzi na postawione w niniejszym tekście pytanie o ich znaczenie w badaniach dotyczących drugiej wojny światowej oraz doświadczenia Żydów i Żydówek w Jugosławii.

Konieczne w tym miejscu wydaje się przybliżenie biografii Kohn ze szczególnym zaakcentowaniem tych faktów, które bezpośrednio wiążą się z tematem analizowanych źródeł. Przyszła fotografka urodziła się w 1914 r. w Rijece. Bieg jej życia został mocno naznaczony przez wydarzenia pierwszej oraz drugiej wojny światowej. W pierwszym wypadku wiąże się to ze śmiercią ojca (Bernarda Kohna), który jako żołnierz armii austro-węgierskiej trafił w 1915 r. do niewoli w Nišu (Serbia), gdzie zaraził się tyfusem i w tym samym roku zmarł. To zdarzenie zmusiło matkę Elviry (Gizelę Kohn, z domu Klein) wraz z dziećmi (drugie z nich to urodzony w 1912 r. Aleksandar) do przeprowadzki do miejscowości Vinkovci, gdzie mieszkała jej rodzina ${ }^{35}$. Gizela Kohn w nowym miejscu pełniła

${ }^{31}$ Informacje na temat projektu oraz bazę danych odnaleźć można na stronie internetowej Centropy: www.centropa.org [dostęp: 28.02.2017].

${ }^{32}$ Zob. Preserving Jewish memory - Bringing history to life: Elvira Kohn, 2003 [online], http:// www.centropa.org/biography/elvira-kohn [dostęp: 28.02.2017]. Wypowiedź Elviry Kohn jest dostępna niestety tylko w języku angielskim. Nie udało mi się dotrzeć do oryginalnych nagrań z rozmowy. Przypomnieć należy również, że w 1987 r. Dubravka Peić na podstawie rozmowy z Kohn przygotowała jej opis biograficzny (do dziś nieopublikowany) na potrzeby Muzeum Historycznego Chorwacji. Zob. L. Benyovsky, Fašistički logor Kampor na Rabu prema sačuvanim bilješkama Elvire Kohn, w: Antisemitizam, Holokaust, Antifašizam, red. I. Goldstein, Židovska općina Zagreb, Zagreb 1996, s. 214, przypis 2.

${ }^{33}$ Wszystkie te materiały znajdują się w archiwum Muzeum Historycznego Chorwacji. Dziennik - numer inwentarzowy HPM 82829/1, wiersz - numer inwentarzowy HPM 82829/2, list - numer inwentarzowy HPM 82830. W dalszej części artykułu, ze względu na jego ograniczone ramy, analizie zostaną poddane dwa pierwsze dokumenty.

${ }^{34}$ Zob. np. R. Ivanuš, dz. cyt., s. 3.

${ }^{35}$ Rodzina Elviry Kohn nie była bardzo religijna, ale przestrzegała niektórych zwyczajów i tradycji żydowskich. W wywiadzie dla Centropy Kohn przedstawiła interesujący opis życia społeczności żydowskiej w Vinkovcach w okresie międzywojennym, zob. Preserving Jewish memory... 
głównie obowiązki gospodyni domowej (podobnie jak jej matka) i opiekowała się dziećmi, tylko przez pewien czas pracowała $\mathrm{w}$ sklepie $\mathrm{z}$ drobiazgami jako sprzedawczyni. Elvira w Vinkovcach ukończyła szkołę podstawową oraz średnią, a następnie rozpoczęła naukę w prywatnym Studiu Fotograficznym „Seiler”. Tam zdobyła doświadczenie w handlu, przede wszystkim jednak opanowała warsztat fotograficzny i - jak sama stwierdziła - pokochała tę formę sztuki ${ }^{36}$. Z czasem bardziej niż fotografia portretowa zaczęła zajmować ją dokumentacja fotograficzna. Gdy od jednego z klientów otrzymała propozycję pracy w charakterze fotoreporterki, zdecydowała się podjąć to wyzwanie i w roku 1932 przeniosła się do Dubrownika, gdzie rozpoczęła pracę w Studiu Fotograficznym „Jadran” u Miha Ercegovicia. Tam do jej obowiązków należało fotografowanie różnych wydarzeń o charakterze kulturalnym, politycznym i religijnym, które odbywały się w Dubrowniku i jego okolicy. Rola Kohn była ograniczona wyłącznie do robienia zdjęć, nigdy nie pisała tekstów jako dziennikarka. Wkrótce po rozpoczęciu przez Elwirę pracy dołączyła do niej matka, która przejęła w nowym miejscu tradycyjnie przypisywane kobiecie obowiązki i zajęła się domem. Jak stwierdziła Elvira Kohn: "She took care of our house and of me. Apart from my work, I didn't have to take care of anything because my mother was there" "37. Dzięki stałej obecności matki Elvira mogła całkowicie skupić się na swoim fotograficznym powołaniu. Nigdy nie wyszła za mąż. Kohn niewiele miejsca w swoich wspomnieniach poświęca tej kwestii. W wywiadzie z Šeljak zaledwie nadmienia, że jej sposób życia nigdy nie był tolerowany przez mężczyzn, miłością jej życia stała się fotografia, w której się spełniała i rozwijała. W 1936 r. zdała egzamin mistrzowski. Trzeba jednak uświadomić sobie, że w okresie międzywojennym sytuacja kobiet na rynku pracy była skomplikowana i w dużej mierze ograniczona prawnie. Szczególnie trudna, jak wykazała Dubravka Peić Čaldarović, była ona w przypadku kobiet zamężnych, które - by podjąć pracę czy kontynuować naukę - potrzebowały zgody męża ${ }^{38}$. Niewykluczone, że zawód Elviry Kohn, wykraczający poza domową przestrzeń tradycyjnie przypisywaną kobiecie, mógł być przez nią wykonywany właśnie dzięki temu, że była kobietą niezależną, niezwiązaną poprzez instytucję małżeństwa. Osobą stale obecną w jej życiu była tylko matka, tak pozostało do śmierci Gizeli Kohn w 1977 r. Można zaryzykować stwierdzenie, że w relacji matka-córka został wypracowany taki model życia, w którym wewnętrzny, kulturowy podział ról pomiędzy kobietami na typowo „żeńskie” i „męskie” stworzył Elvirze warunki do przekroczenia obowiązujących norm społecznych oraz wkroczenia w domenę obowiązków i przywilejów (wejście w sferę aktywności pub-

36 Tamże.

37 Tamże.

38 Zob. analizę aktów prawnych z okresu 1918-1941, dotyczących prawa kobiet do głosowania, do pracy i do wynagrodzenia - D. Peić Čaldarović, „Ženska posla” između obitelji i profesije, „Otium” 1999-2000, nr 7-8, s. 66-74. 
licznej), które łączone były ze światem męskim. Ten niezwykły kobiecy układ mógłby stanowić potwierdzenie, że ,linia pomiędzy tym, co publiczne, a tym, co prywatne, nie przebiega schematycznie i dokładnie przez płeć" 39 . Swoisty podziw budzi też determinacja i stałość fotografki w podążaniu obraną przez nią drogą zawodową ${ }^{40}$. Branka Hlevnjak udowadnia, że w pierwszej połowie XX w., od roku 1925, czyli od czasu seryjnej produkcji lekkich i niewielkich rozmiarów aparatów marki leica, w których szklane płytki zostały zastąpione przez błony fotograficzne, można mówić w Chorwacji o upowszechnieniu i swoistej popularności fotografii, również wśród kobiet ${ }^{41}$. Jednakże burzliwa historia tamtego czasu zadecydowała o tym, że to właśnie Elvira Kohn zajmie w dziejach chorwackiej fotografii miejsce wyjątkowe.

Druga wojna światowa rozpoczęła kolejny cykl wydarzeń, które na zawsze zmieniły losy rodziny Kohn. Członkowie ze strony ojca (dziadkowie i jedna siostra, Malvina, zmarli przed wojną), w tym dwóch braci (Sandor i Emil), siostra (Elza) oraz ich rodziny zginęli w Auschwitz. Przeżyła tylko jedna z sióstr, Olga, która wyjechała do Belgradu, wyszła za mąż za prawosławnego Serba i przyjęła jego wiarę. Bracia Gizeli Kohn (Samuel i Drgautin) zginęli w obozie Jasenovac. Jedna z sióstr przeżyła wojnę, gdyż w 1929 r. wyemigrowała do Brazylii. Druga z nich, Tereza, jej córka oraz rodzice sióstr (dziadkowie Elviry Kohn) trafili do obozu Stara Gradiška, podobozu kompleksu Jasenovac, i tam stracili życie. Przeżyła druga z córek Terezy, która mieszkała w Dubrowniku i stamtąd trafiła do włoskiego obozu Feramonti. Po wojnie wyjechała do Izraela. Elvira Kohn, w kontekście tragicznych dziejów swoich bliskich, historię śmierci swojego brata przytaczała jako przykład upiornej ironii. Aleksandar wyjechał przed wojną do Belgradu, gdzie pod opieką ciotki Olgi rozpoczął pracę. Tam zmarł w nieszczęśliwych okolicznościach - w zderzeniu z rowerzystą upadł i uderzył głową o krawężnik. Wypadek miał miejsce w 1937 r. Aleksandar został pochowany na belgradzkim cmentarzu żydowskim. Gdyby dożył czasów wojny, prawdopodobnie zginąłby w jednym $z$ niemieckich obozów i miejsce jego pochówku byłoby nieznane ${ }^{42}$.

Elvira Kohn wraz z matką w czasie wybuchu wojny znajdowały się na terenie Dubrownika. Wraz z proklamacją NDH w kraju została wprowadzona seria rozporządzeń ograniczająca prawa Żydów, w tym również zakaz pracy. Mimo to

${ }^{39}$ I. Iwasiów, Wstęp: Studia kobiece: między ,ja”, światem a literatura, w: Prywatne/publiczne. Gatunki pisarstwa kobiecego, red. I. Iwasiów, Wydawnictwo Naukowe Uniwersytetu Szczecińskiego, Szczecin 2008, s. 7.

${ }^{40}$ Okres międzywojenny był również dla Serbek czasem wchodzenia w nowe role społeczne. Jako przykład może posłużyć Milica Jakovljević, zwana Mir Jam (1887-1952), jedna z pierwszych serbskich dziennikarek i autorka bardzo popularnych utworów beletrystycznych. Zob. M. Koch, Kobiece narracje o Wielkiej Wojnie w serbskiej literaturze popularnej okresu międzywojennego (casus Milicy Jakovljević - Mir Jam), „Porównania” 2015, nr 16, s. 103-124.

${ }^{41}$ B. Hlevnjak, dz. cyt., s. 19.

42 Preserving Jewish memory... 
Miho Ercegović pozwalał Elvirze jeszcze przez pewien czas nieoficjalnie kontynuować pracę. W listopadzie 1942 r. wszyscy Żydzi (grupa około 1200 osób) zostali zmuszeni do opuszczenia miasta. Ercegović nie przyjął od Elviry aparatu leica, którym na co dzień pracowała, lecz prosił, żeby zabrała go ze sobą i podarował jej dodatkowo dziesięć filmów fotograficznych ${ }^{43}$. Początkowo Żydzi przebywali w Gružu, kilka kilometrów od Dubrownika. Po dwóch miesiącach, w styczniu 1943 r. zostali przeniesieni do miejscowości Kupari, a w maju tego samego roku na wyspę Rab do obozu Kampor. Po kapitulacji Włoch we wrześniu 1943 r. obóz został zlikwidowany. Elvira i Gizela Kohn przyłączyły się do ruchu partyzantów. Matka początkowo pracowała w dziale kuchennym, następnie w jednostce opieki zdrowotnej. Elvira zaczęła pracę jako fotografka w dziale informacji i propagandy Krajowej Antyfaszystowskiej Rady Wyzwolenia Narodowego Chorwacji (ZAVNOH), która miała pełnić funkcję najwyższego organu władzy w Chorwacji w ramach Antyfaszystowskiej Rady Wyzwolenia Narodowego Jugosławii $(\mathrm{AVNOJ})^{44}$. W tym charakterze, jako jedyna kobieta fotoreporterka w obrębie ZAVNOH, pracowała do końca 1943 r.. Następnie od początku roku 1944 robiła zdjęcia dla sekcji agitacji i propagandy Komitetu Centralnego Komunistycznej Partii Chorwacji ${ }^{45}$. Po zakończeniu wojny Elvira zamieszkała razem z matką w Zagrzebiu i tam kontynuowała pracę w swoim zawodzie ${ }^{46}$. Jej zdjęcia były publikowane m.in. na łamach czasopism „Vjesnik” i „Naprijed”. Była członkiem partii komunistycznej, ale jednocześnie starała się uczestniczyć w życiu gminy żydowskiej.

\section{Elvira Kohn jako fotografka ${ }^{47}$}

Branka Hlevnjak, komentując dorobek fotograficzny Elviry Kohn, stwierdziła, że gdyby fotografka wykonała tylko zdjęcie $A$ kuda sada? (A dokąd teraz?), do którego odwołuję się w tytule niniejszego artykułu, wystarczyłoby to, aby na

${ }^{43}$ B. Hlevnjak, dz. cyt., s. 76. Instytut Yad Vashem przyznał Mihowi Ercegoviciowi i jego synowi Velimirowi w 1997 r. odznaczenie Sprawiedliwych wśród Narodów Świata. Więcej na ten temat zob. The Righteous Among The Nations: Ercegović Family, Yad Vashem [online], http:// db.yadvashem.org/righteous/family.html?language=en\&itemId=4042602 [dostęp: 28.02.2017].

${ }_{44}$ M.J. Zacharias, Polityka KPJ i kwestia narodowościowa w Jugosławii w latach 1919-1943, „Studia z Dziejów Rosji i Europy Środkowo-Wschodniej”, t. 39 (2004), s. 55.

${ }^{45}$ L. Benyovsky, dz. cyt., s. 223.

${ }^{46}$ Czasem błędnie podaje się, że Elvira Kohn po 1945 r. przerwała pracę jako fotoreporterka, zob. Zanimljive žene...

${ }^{47}$ Fotografie wykonane przez Elvirę Kohn w czasie wojny znajdują się w archiwum Muzeum Historycznego Chorwacji, fotografie z okresu powojennego, razem z obszerną dokumentacją z działalności w dziale fotograficznym Jugosłowiańskiej Armii Ludowej (1950-1964), są przechowywane w Chorwackim Archiwum Państwowym (numer inwentarzowy 1211 5.VoJNA). 
trwałe zapisała się w historii chorwackiej fotografii. Sportretowana na nim matka z dziećmi to niewątpliwie jeden z najciekawszych obrazów autorstwa Kohn. Zdjęcie zostało wykonane w 1944 r. w miejscowości Topusko. Centralne miejsce na fotografii zajmuje siedząca na krawężniku kobieta, wokół której po jednej stronie leżą spakowane w torby rzeczy oraz blaszane naczynie na mleko, jedyne przedmioty, jak pisze Hlevnjak, przypominające o utraconym domu ${ }^{48}$. Zaś przed nią i za nią znajdują się kilkuletnie dzieci. Motyw ten odnaleźć można również na słynnym zdjęciu z 1936 r. amerykańskiej fotografki Dorothei Lange, zatytułowanym Migrant mother (Matka tułaczka), które zostało wykonane w Stanach Zjednoczonych w czasie kryzysu gospodarczego ${ }^{49}$. Bohaterka zdjęcia Kohn ubrana jest w prosty strój, jej głowę owija chustka, jedna z jej rąk schowana jest pod ramię, drugą natomiast dotyka swojej twarzy, jak gdyby ją przykrywała. Strój kobiety i widoczne na twarzy strapienie wskazują na jej trudne położenie. Otaczające ją skromnie ubrane, bose dzieci są albo zajęte zabawą, albo odpoczywają. Ich uwagę pochłania jakiś element zewnętrzny. Jednak tym, co dominuje w obrazie, jest spojrzenie kobiety. Jej twarz, jak się wydaje, odgrywa znaczącą rolę ze względu na temat portretu. Autorce zdjęcia udało się bowiem uchwycić w tym spojrzeniu tytułowe pytanie, którego sens można by sparafrazować za pomocą innych pytań - „Co dalej? Jak żyć?”. W szeregu tych niepewności doszukiwać się można myśli matki, w których zawiera się zawieszenie, tymczasowość, czekanie i jednocześnie bezradność wobec okoliczności, które ją otaczają i na które nie ma wpływu. Czas wykonania zdjęcia to kolejny rok wyniszczającej wojny, dotykającej wszystkich mieszkańców kraju. Co ciekawe, oczy kobiety nie spotykają się ze wzrokiem patrzącego na zdjęcie widza, lecz są skierowane w jakieś inne, odległe miejsce. Tymczasem, mimo że spojrzenia w relacji bohaterka-patrzący mijają się, wyraźnie dochodzi do „wymiany spojrzeń” pomiędzy autorką zdjęcia i odbiorcą ${ }^{50}$. Jak podpowiada Hlevnjak, temat fotografii można rozumieć szeroko jako zobrazowanie uniwersalnego Zła, wszechobecnego i towarzyszącego człowiekowi od zawsze, które za nic ma ludzkie życie oraz niszczy niewinność dzieci i godność człowieka $^{51}$. Dodatkową wartością, która wzmacnia siłę przekazu i bez wątpienia wpłynęła również na sposób widzenia świata przez autorkę zdjęcia, jest doświadczenie Kohn, która w momencie robienia zdjęcia ma za sobą przeszłość obozową oraz łączące się z nią tragedię i poniżenie. Fotograficzną konstrukcję, czyli portret psychologiczny matki, wzmaga jeszcze czarno-biała, antyestetyczna poetyka.

\footnotetext{
${ }^{48}$ B. Hlevnjak, dz. cyt., s. 75.

49 Tamże.

${ }^{50}$ Hans Belting wyjątkowość fotografii rozumiał właśnie jako „medium między dwoma spojrzeniami", cyt. za: A. Hudzik, Holokaust w obrazach fotograficznych, w: Teoria obrazu w naukach humanistycznych, red. K. Chmielecki, B. Lisowska, Wydawnictwo Akademii Humanistyczno-Ekonomicznej, Łódź 2015, s. 111-112.

${ }^{51}$ B. Hlevnjak, dz. cyt., s. 75.
} 
W przypadku fotografii Elviry Kohn poszczególne obrazy należałoby analizować osobno, jako odrębne całości (na co nie ma w pełnym wymiarze miejsca w niniejszym tekście). Szczególnie oczekiwane jest to wtedy, gdy mowa o zdjęciach z okresu wojny. Choć niewątpliwie podstawowym celem praktyk fotograficznych Kohn była wówczas chęć dokumentowania czy upamiętnienia, to jednak odbiorca zdjęć może wejść w pewien „dialog z dokumentalnością obrazu”52. Widz może to zrobić, wykorzystując nie tylko własne umiejętności interpretacyjne, ale również z uwzględnieniem kontekstu, w który uwikłane są obraz oraz jego twórczyni. Takie refleksyjne podejście do fotografii - którego propagatorką w Polsce jest Marianna Michałowska - wymagające od widza zadawania sobie pytań o cel, okoliczności powstania i funkcjonowanie fotografii, czyli osadzenie obrazu w kontekście narracyjnym, pozwala wydobyć z niej nowe, istotne bogactwo sensów ${ }^{53}$. Fotografię, będącą jednocześnie tekstem kultury i zapisem doświadczenia, można by określić jako foto-tekst, który Michałowska definiuje jako: ,[i] tencjonalnie wytworzoną konstrukcję, odnoszącą się do fotograficznych obrazów materialnych obiektów, reprezentującą kulturowe znaczenia i indywidualne doświadczenia odbiorców" 54 . W tym momencie warto bliżej przyjrzeć się zdjęciom, które zostały wykonane przez Kohn na wyspie Rab.

Elvira Kohn jako więźniarka obozu Kampor, obawiając się o swoje bezpieczeństwo, nie wykonała żadnych zdjęć. Samo przechowywanie aparatu niosło ze sobą wysokie ryzyko. Kohn podkreślała, że tylko dzięki pomocy innych więźniów udało jej się ukrywać leicę przed strażnikami obozu ${ }^{55}$. Pierwsze zdjęcia wykonała po kapitulacji Włoch i likwidacji obozu. Te fotografie można podzielić tematycznie na dwie grupy ${ }^{56}$. Pierwsza $z$ nich zawiera obrazy przedstawiające zabudowę obozu, druga obejmuje zdjęcia ukazujące postaci byłych więźniów. Janina Struk w ważnej monografii Holokaust w fotografiach wprowadza proste, ale istotne rozróżnienie na fotografie wojenne i fotografie Holokaustu. Wyjściowy podział, który autorka niuansuje w trakcie swojej analizy, jest niezbędny, by wyróżnić z ogromu dokumentacji fotografie utrwalające Zagładę ${ }^{57}$. W przypadku zdjęć autorstwa Kohn rodzi się pytanie, do której grupy należałoby je dołączyć. Nie są to zdjęcia „,ukazujące zabitych zaściełających pole bitwy ani niszczyciel-

${ }^{52}$ M. Michałowska, Foto-teksty. Zwiazki fotografii z narracja, Wydawnictwo Naukowe UAM, Poznań 2012, s. 18.

53 Tamże.

${ }^{54}$ Tamże, s. 12.

${ }^{55}$ Preserving Jewish memory...

${ }^{56}$ Niestety, część fotografii wykonanych bezpośrednio po wyjściu z obozu została zagubiona w 1944 r., gdy Elvira Kohn pracowała dla oddziałów partyzanckich. Więcej na ten temat zob. L. Benyovsky, dz. cyt., s. 222-223.

57 J. Struk, Holokaust w fotografiach. Interpretacje dowodów, przekł. M. Antosiewicz, Prószyński i S-ka, Warszawa 2007, s. 22. 
skie skutki wojny dla ludności cywilnej"58. Nie są to również świadectwa dokumentujące Holokaust. Jednak nie są to też, jak mi się zdaje, zdjęcia stanowiące wyłącznie zapis istnienia włoskich obozów, choć oczywiście ta ich funkcja odgrywa ważną rolę jako materiał historyczny. Zdjęcia Elviry Kohn z grupy prezentującej strukturę i budynki obozu zostały wykonane w różnych ujęciach. Pierwsze z nich to perspektywa panoramiczna, wykonana $\mathrm{z}$ daleka, z pewnej wysokości, której celem jest ukazanie możliwie szerokiego spojrzenia na rozległy teren obozu. Kolejne to widok wykonany w środku obozu, w przejściu pomiędzy budynkami, ukazujący układ baraków. Trzecie to zdjęcie zrobione w węższym kadrze, na którym widać trzy budynki obozowe. Kluczowe jednak dla jego istoty jest to, że na pierwszym planie widnieje ogrodzenie z drutu. Fotografia została wykonana z perspektywy osoby z zewnątrz, która zza drutów obserwuje obóz. W zdjęciach Elviry Kohn można zaobserwować dążenie do obiektywizmu, wspomnianej dokumentacyjnej potrzeby archiwizacji. Zbiór fotografii budynków można rozpatrywać jako próbę wykonania zdjęć, które przede wszystkim stanowić mają czytelne źródło poświadczające istnienie włoskich obozów koncentracyjnych i warunki życia w nich. Obrazy fotograficzne tworzą narzędzie do opowieści o rzeczywistości obozu. Jednak, co szczególnie uwidacznia się w ostatnim ujęciu, Elvira Kohn w swoim zamyśle uchwycenia różnych perspektyw, swoistej gry kadrami, wykonuje nawet coś więcej, eksplorując obszary poobozowe. Przekracza ramy fotografii instrumentalnej rejestrującej stan rzeczy i - jako była więźniarka - ukazuje tożsamość pozornie „niewinnych” budynków, miejsc cierpienia wielu ludzi.

Zupełnie odmiennie prezentują się zdjęcia z drugiego zestawu ${ }^{59}$, który stanowi niejako kontynuację pierwszego zbioru. Na tych fotografiach cisza towarzysząca milczącym budynkom zostaje zastąpiona gwarem i śmiechem ludzi, byłych więźniów świętujących kapitulację Włoch i wyzwolenie z obozu. Budzącą strach atmosferę uwięzienia obecną na poprzednich pracach zastąpiła radość płynąca $\mathrm{z}$ dobrych wieści. $Z$ jednej strony na omawianych fotografiach widać zgromadzenie byłych więźniów, którzy wysłuchują przemowy i w geście radości, podobnie jak mówca, podnoszą do góry zaciśniętą w pięść rękę. Z drugiej strony, Kohn wykonała zdjęcie pozowane. Znajduje się na nim zwrócona w stronę obiektywu grupa ludzi, byłych więźniów i partyzantów ${ }^{60}$, entuzjastycznie ustawiających się do zdjęcia. Nad nimi trzymana jest pokaźnych rozmiarów flaga Narodowej Armii Wyzwolenia Jugosławii z umieszczoną w centrum socjalistyczną pięcioramienną

\footnotetext{
${ }^{58}$ Tamże.

${ }^{59}$ Mam tu na myśli zdjęcia o numerze trzy i cztery z katalogu wystawy Rhei Ivanuš, czyli fotografie zatytułowane Internirci (Internowani) oraz Smrt fašizmu... (Śmierć faszyzmowi...). Zob. R. Ivanuš, dz. cyt., s. 18.

${ }^{60}$ Choć tytuł zdjęcia w katalogu z wystawy z 1997 r. to Internirci, wśród pozujących do zdjęć obecni są również partyzanci.
} 
gwiazdą (tzw. petokraka). Fotografie również w tym przypadku przekazują zarówno obraz, jak i związaną z nim narrację, w której dostrzec można wyraźny znak obecności autorki. Elvira Kohn na obu fotografiach tworzy dwuplanowy obraz - pierwszy z postaciami ludzi, drugi z tłem składającym się z obozowych budynków. W obu przypadkach autorka starała się zatrzymać moment, który wyraża - na zasadzie kontrastu z wcześniejszymi materiałami - emocje odwrotne do tych, które zazwyczaj przypisujemy sytuacji przebywania w obozie. Obserwować można interakcję, choć w zasadzie jej brak, pomiędzy byłymi więźniami a miejscem ich izolacji. Relacja pomiędzy osobą a miejscem pozostała, ale zniknęło, przynajmniej na chwilę, wiążące się z nią napięcie. Dopiero w zestawieniu i etapowym prześledzeniu kolejnych obrazów stworzonych przez Kohn możliwe jest poznanie głębi zdjęć jej autorstwa.

\section{Elvira Kohn jako pisarka}

Fotograficzna spuścizna Elviry Kohn nie powinna budzić wątpliwości co do wartości historycznej i artystycznej. Z odmienną sytuacją mamy do czynienia w przypadku pozostawionych przez Kohn świadectw pisanych, spoczywających w archiwum Muzeum Historycznego Chorwacji. Prawdopodobnie częściowo za taki stan rzeczy może odpowiadać sama Kohn, która uważała siebie przede wszystkim za profesjonalną fotografkę i we wspomnieniach kładła nacisk na fakt, że nigdy nie zajmowała się tekstualną oprawą swoich zdjęćct. Z drugiej jednak strony zapiski z obozu na wyspie Rab zachowała przez całe życie i wraz z fotografiami przekazała do archiwum, a więc miała świadomość ich znaczenia jako dokumentów poświadczających przeszłość. Z kolei, szczególnie „w czasach traumy i czasach świadectwa" (Natka Badurina) ${ }^{62}$, dziwić może niewielkie zainteresowanie, jakie wzbudziły teksty u historyków i badaczy literatury. Wydaje się, że kategorią, która trafnie ujmuje istotę tych dokumentów osobistych jest termin 'twórczości niepozornej', po raz pierwszy użyty przez Jerzego Strzelczyka do opisu głównie użytkowego pisarstwa kobiet epoki średniowiecza ${ }^{63}$. Jednak, jak przekonują studia zawarte w tomie Twórczość niepozorna z 2015 r., pojęcie to bez wątpienia (choć nie bez ograniczeń) może być stosowane również do ana-

\footnotetext{
${ }^{61}$ Preserving Jewish memory...

${ }^{62} \mathrm{~N}$. Badurina, Vrijeme traume, vrijeme svjedočenja. Testimonijalna literatura i književni kanon tijekom dvadesetog stoljeća, w: Istodobnost raznodobnog. Tekst i povijesni ritmovi, red. C. Pavlović, V. Glunčić-Bužančić, A. Meyer-Fraatz, Književni krug, Odsjek za komparativnu književnost Filozofskog fakulteta Sveučilišta u Zagrebu, Split-Zagreb 2010, s. 189-201.

${ }^{63}$ J. Strzelczyk, Pióro w wątych dłoniach. O twórczości kobiet w wiekach dawnych, t. 1-2, Wydawnictwo DiG, Warszawa 2007-2009.
} 
lizy literatury nowoczesnej ${ }^{64}$. Inga Iwasiów w artykule wstępnym tomu rozważa potencjał tej kategorii i jednocześnie przestrzega przed zbyt pochopnym jej używaniem. „Niepozorne” to zatem takie teksty, które mogą podlegać kulturowej marginalizacji, zdają się ,na pierwszy rzut oka nieefektowne, niezgodne z naszymi przyzwyczajeniami”, są lapidarne w formie, „obrazują codzienność swych narratorów" $"$.

Zapiski wspomnieniowe Elviry Kohn zaczęły powstawać krótko po jej dotarciu do obozu Kampor. Obejmują 12 i pół strony, początkowo były zapisywane atramentem, ale już od trzeciej strony autorka używa ołówka. Wspomnienia nie są datowane. Rozpoczynają się przywołaniem momentu przybycia na wyspę Rab, najpierw parostatkiem, a następnie ciężarówkami bezpośrednio na teren obozu. Po dotarciu, ze względu na ciasnotę, nowo przybyłych porozdzielano do różnych obozów wewnętrznych ${ }^{66}$. Mimo trwającego od kilku miesięcy życia wygnańca, dopiero tutaj, jak pisze Kohn, zaczął się dla nich ,pravi logorski život”67. Tym, co szczególnie mocno wpłynęło na pogorszenie ówczesnego stanu więźniów był ujrzany rano po pierwszej spędzonej w obozie nocy drut tworzący ogrodzenie, oddzielający od siebie sektory obozu, a więc grupy więźniów, w tym również tych, którzy spędzili razem ostatnie miesiące. Drut podzielił ich w sensie dosłownym, ale też symbolicznie przegrodził życie na czas przed obozem i czas izolacji. Tutaj poczuli się jak dzikie zwierzęta zamknięte w klatce, którym trzeba rozkazywać krzykiem. Więźniowie nie mogli zbliżać się do ogrodzenia ani ze sobą rozmawiać. Szczególnie dotkliwie to o(d)graniczenie, jak pisze Kohn, odczuli rodzice rozdzieleni z dziećmi oraz rodzeństwa. Przedzielający obóz drut powraca w tych skromnych zapiskach kilkakrotnie.

Wbrew tym pierwszym wrażeniom początki życia w obozie minęły stosunkowo spokojnie. Notatki Kohn są zwięzłe i treściwe. Pisze mało, bo w jej sektorze nie działo się nic szczególnego. Odnotowuje wzruszające spotkania członków rodzin, którzy nie widzieli się od czasu rozstania w domu. Wieczory upływały więźniom wręcz przyjemnie, przy muzyce i śpiewie. Był to czas chwilowego zapomnienia i uwolnienia od wszystkich trosk.

Kolejne ważne wydarzenie zapisane przez Kohn jest związane z przybyciem nowych grup więźniów (z Lopuda i Kraljevicy). Problemem okazał się brak wody

${ }^{64}$ Zob. Twórczość niepozorna. Szkice o literaturze, red. J. Grądziel-Wójcik, A. Kwiatkowska, L. Marzec, Wydawnictwo Pasaże, Kraków 2015.

${ }^{65}$ I. Iwasiów, Twórczość niepozorna na barykadzie codzienności, w: Twórczość niepozorna..., s. $17-26$.

${ }^{66}$ Obóz na wyspie Rab składał się z trzech sekcji: dubrownickiej (przeznaczonej dla Żydów z Dubrownika, których wcześniej izolowano w miejscowości Kupari), zagrzebskiej (dla Żydów z miejscowości Kraljevica) oraz słoweńskiej (dla Słoweńców z anektowanych części Słowenii). Zob. L. Benyovsky, dz. cyt., s. 218.

${ }^{67}$,prawdziwe życie obozowe”. Przekład filologiczny cytowanych fragmentów jest mojego autorstwa - K.T. 
w sektorze, w którym zostali ulokowani nowo przybyli. Zmęczenie więźniów drogą dodatkowo potęgowane było wysoką temperaturą powietrza. Inne grupy zareagowały natychmiast i mimo dzielącego ich ogrodzenia zaczęły przekazywać spragnionym butelki i naczynia z wodą. Sprawną pomoc przerwał pełniący wartę oficer, który zabronił podawania wody i kazał odizolować tych, którzy to robili. Problem wody Kohn przywołuje również w dalszej części zapisków. Przy okazji opisanego gestu pomocowego warto wspomnieć także o akcie solidarności okazanym odseparowanym więźniom. Po tej interwencji więźniów zwolniono, choć trwało jeszcze wewnętrzne dochodzenie. W jego trakcie jeden z podających wodę, po przyznaniu się do „winy”, został uderzony przez kapitana. Na wieść o tym cały obóz, by wesprzeć „winowajców”, odmawiał podjęcia pracy. Reakcją ze strony włoskiej było zwołanie zgromadzenia, na którym więźniowie usłyszeli: „Mi smo ovd[j]e da zaštićujemo one koji slušaju i vrše naša naređenja, a za ostale imamo oružja dosta da vas sravnimo sa zemljom"68.

Kohn utrwala we wspomnieniach jeszcze jedno ciekawe zdarzenie związane z więźniarkami. Poza wykonywaną obowiązkową pracą możliwe było również podjęcie pracy dobrowolnej, za którą otrzymywano dodatkową porcję jedzenia. Wiele osób godziło się na to, jednak zdarzały się również odmowy współpracy. Kohn opisuje poszukiwania sanitariuszek do obozowego szpitala. Kobiety niechętnie podejmowały tę pracę ze względu na fakt, iż zamiast pracy pielęgniarskiej tak naprawdę miały wykonywać pracę sprzątaczek: ,[t]e bolničarke ne vrše stvarno tu dužnost nego su im bile potrebne pralje, sob. [sobarice] $i$ služavke ali pod imenom bol.[ničarki] su ih ht[j]eli otpremiti u boln. [bolnicu]" ${ }^{\prime 69}$. Więźniarki, które chciano zmusić do pracy, a one zdecydowanie i odważnie nie wyraziły na to zgody, zostały ukarane (kilkugodzinnym staniem przed komendantem i zakazem mycia). Jeszcze wiele lat później, gdy Kohn wracała do wspomnień dotyczących pracy, akcentowała, że w obozie nigdy nie zgadzała się na wykonywanie zadań typu „przyszywanie guzików do munduru”, mimo płynących z tego korzyści ${ }^{70}$. Część dziennikową zamykają zdania umiejscowione po wierszu, informujące o wyzwoleniu obozu i radości płynącej z odzyskanej wolności.

Niepozorność zapisków Kohn tkwi zarówno w ich statusie jako materiałów dokumentujących pobyt $\mathrm{w}$ obozie ${ }^{71}$, jak i ze względu na lakoniczną formę. Jedno-

68 „Jesteśmy tutaj, by chronić tych, którzy słuchają i wykonują nasze rozkazy, dla pozostałych mamy dość broni, by was zrównać z ziemią".

69 ,[t]e pielęgniarki tak naprawdę nie wykonują swoich obowiązków, lecz były im potrzebne praczki, pokojówki, służące, ale pod tą nazwą pielęgniarek chcieli je wysłać do szpitala”.

${ }^{70}$ Preserving Jewish memory...

${ }^{71}$ Niepozorność pozycji wspomnień może być rozważana również w przypadku innej byłej więźniarki obozu na wyspie Rab. Chodzi o Milenę Mohorovičevą, autorkę opowiadań Motivi z Raba (Motywy z Raba, Ljubljana 1946), która z powodu swoich poglądów politycznych po 1948 r. została umieszczona w zakładzie psychiatrycznym. Zob. N. Badurina, Vrijeme traume..., s. 190, przypis 1 . 
cześnie wspomnienia dostarczają informacji na temat wydarzeń oddziałujących na życie jednostki. Narracja Kohn, stanowiąca zapis jej indywidualnej mikrohistorii $^{72}$, codzienności doświadczanej w obozie dla Żydów na wyspie Rab, osadzona w kontekście makronarracji tzw. wielkiej historii, daje nam wgląd w rzeczywistość włoskich obozów koncentracyjnych. Wydaje się, że tekst autorstwa byłej więźniarki i wykonane przez nią fotografie są wobec siebie komplementarne, wchodzą ze sobą w interakcję i tworzą jedną narrację. W ich wnikliwej analizie należałoby je ze sobą połączyć, gdyż dopiero w takim kalejdoskopowym zestawieniu czytelniejsze staje się ich znaczenie.

Niestety, czytelnik, który podejmuje próbę odczytania archiwalnych zapisków, napotka jeszcze jedną przeszkodę, która częściowo uwidoczniła się już w cytowanych powyżej fragmentach dziennika, a która dobitnie przejawia się w wierszu. Chodzi o stosowane przez autorkę skróty, brak zapowiedzianych wątków (np. obozu znajdującego się naprzeciwko dubrownickiego), skreślenia, literówki oraz - wynikające z upływu czasu i oddziaływania warunków zewnętrznych - uszkodzenia: złamania stron, przetarcia lub wyblaknięcie papieru. W efekcie odtworzenie w całości wiersza Kohn jest zadaniem niemożliwym. Jednakże, jak to na przykładzie fotografii (z) Zagłady pokazał przejmująco Jacek Leociak: „Dzięki warstwie uszkodzeń «przeszkadzających»w odbiorze obraz zostaje niejako uaktualniony, patyna dawności, aura czasu minionego - zakwestionowane"73. W wyniku zakłóconego odbioru widz/czytający zostaje przeniesiony ,z bezpiecznego «tu i teraz» do niepokojącego «tam i wtedy»" 74 . Wiersz, mimo podziału na części formalne pisane dwunastozgłoskowcem oraz dwie tematyczne, poświęcone cierpieniom zaznanym w obozie oraz radości po wyzwoleniu, sprawia wrażenie niedoskonałego, niedokończonego i niedopracowanego, ale jest równocześnie świadectwem tworzenia w pośpiechu, wbrew realiom obozowym. Zaobserwować można wyraźne ambicje artystyczne autorki, świadomie wykorzystującej strategie twórcze. Mimo że na wyczerpującą analizę tekstu nie ma miejsca w niniejszym artykule, przyjrzyjmy się choć jego fragmentowi:

Dokle? Dokle Judo? Dokle će to tako?

Pitao je redom, tko je stigo svako

Dokle će ti ljudi progonjeni biti?
Jak długo? Jak długo Judaszu? Jak długo tak będzie?

Pytał po kolei każdy, kto przybył

Jak długo ci ludzie będą prześladowani?

72 E. Domańska, Mikrohistorie. Spotkania w międzyświatach, Wydawnictwo Poznańskie, Poznań 2005, s. 273.

73 J. Leociak, Okaleczone obrazy. Uszkodzone fotografie (z) Zagłady jako wyzwanie interpretacyjne, w: Zagłada. Współczesne problemy rozumienia i przedstawiania, red. P. Czapliński, E. Domańska, Poznańskie Studia Polonistyczne, Poznań 2009, s. 286.

${ }^{74}$ Tamże. 
Dokle će taj narod krv nevinu piti

Odgovor je zasad još pokriven velom

A poznat je svugde čovečanstvu celom

Dokle zveri ima ima u ljudskoj spodobi

Dotle može pakost pravdu da orobi
Jak długo ten naród będzie pił niewinną krew

Odpowiedź na razie jeszcze skrywa welon A znana jest już wszędzie ludzkości całej Dopóty bestie przybierają ludzką postać Dopóki może zło prawdę ograbić

Już pojedyncza strofa potwierdza dążenie Kohn do nadania utworowi formy literackiej, z zachowaniem rytmu i rymu. Poetyckość tekstu zawarta jest ponadto $\mathrm{w}$ natężeniu pytań retorycznych adresowanych do Judasza. Z fragmentu tego uderza patetyczny ton, ogarniający próbę werbalnego opisu zła, spotykającego naród żydowski. Cytat ten ujawnia potencjał warsztatowy autorki, wypełniający również kolejne wersy jej poezji.

\section{Zakończenie}

Niniejszy tekst to zaledwie szkic, który nie rości sobie prawa do pełnej odpowiedzi na pytanie o znaczenie, niepoddających się prostym kategoryzacjom, świadectw fotograficznych i pisemnych autorstwa Elviry Kohn. W swojej analizie ograniczam się do zarysowania perspektywy sytuacji historyczno-politycznej w Jugosławii, w której mieści się obraz przeszłości zarysowany w jej fotografiach i pisanych dokumentach osobistych. Narrację osobistą Kohn traktuję jako materiał uzupełniający wiedzę na temat przeszłości Żydów w Jugosławii, który ze względu na decyzje głównej bohaterki można uznać również za dowód na emancypacyjne przemiany społeczne tamtego okresu oraz za przykład przełamywania istniejących kulturowych paradygmatów. W odniesieniu do twórczości Kohn powiedzieć można, że w pamięci współczesnych zajmuje ona miejsce peryferyjne, oświetlone zaledwie częściowo, które wymaga jeszcze osobnych i starannych studiów. Wydaje się, że historia osobista Kohn daje impuls do badań w myśl założeń historii ratowniczej ${ }^{75}$, która mogłaby stanowić ciekawe wyzwanie dla rekonstrukcji przeszłości Jugosławii lub nawet Bałkanów.

\section{Bibliografia}

Abramac Gabi, Holocaust Revisionism in Croatia: How Anne Frank Became Persona Non Grata, „The Algemeiner” 31.01.2017 [online], https://www.algemeiner.com/2017/01/31/holocaustrevisionism-in-croatia-how-anne-frank-became-persona-non-grata/ [dostęp: 28.02.2017].

\footnotetext{
${ }^{75}$ E. Domańska, Historia ratownicza, „Teksty Drugie” 2014, nr 5, s. 12-26.
} 
Алмули Јаша, Страдање и спасавање српских Јевреја, Завод за уџбенике, Београд 2010.

Badurina Natka, Proučavanje holokausta iz ženske perspektive, w: Sjećanja žena žrtava nacizma i nedemokratskih režima, red. Sandra Prlenda, Centar za ženske studije, Zagreb 2009, s. $35-46$.

Badurina Natka, Vrijeme traume, vrijeme svjedočenja. Testimonijalna literatura i književni kanon tijekom dvadesetog stoljeća, w: Istodobnost raznodobnog. Tekst i povijesni ritmovi, red. Cvijeta Pavlović, Vinka Glunčić-Bužančić, Andrea Meyer-Fraatz, Književni krug, Odsjek za komparativnu književnost Filozofskog fakulteta Sveučilišta u Zagrebu, Split-Zagreb 2010, s. $189-201$.

Badurina Natka, Ženska svjedočenja iz koncentracijskih logora, w: Badurina Natka, Nezakonite kćeri Ilirije, Centar za ženske studije, Zagreb 2009, s. 219-243.

Bajford Jovan, Staro sajmište. Mesto sećanja, zaborava i sporenja, Beogradski centar za ljudska prava, Beograd 2011.

Barbir-Mladinović Ankica, Oholokaustu iz književne perspektive, ,Radio Slobodna Evropa” 12.09.2009 [online], http://www.slobodnaevropa.org/a/holokaust/1820982.html [dostęp: 28.02.2017].

Benyovsky Lucija, Fašistički logor Kampor na Rabu prema sačuvanim bilješkama Elvire Kohn, w: Antisemitizam, Holokaust, Antifašizam, red. Ivo Goldstein, Židovska općina Zagreb, Zagreb 1996, s. 214-223.

Blasin Barbara, Marković Igor, Ženski vodič kroz Zagreb, Meandar, Zagreb 2006.

Centropa [online], www.centropa.org [dostęp: 28.02.2017].

Domańska Ewa, Historia ratownicza, „Teksty Drugie” 2014, nr 5, s. 12-26.

Domańska Ewa, Mikrohistorie. Spotkania w międzyświatach, Wydawnictwo Poznańskie, Poznań 2005.

Dyras Magdalena, Re-inkarnacje narodu. Chorwackie narracje tożsamościowe $w$ latach dziewięćdziesiątych XX wieku, Wydawnictwo Uniwersytetu Jagiellońskiego, Kraków 2009.

Falski Maciej, Rawski Tomasz, Jasenovac, Bleiburg, Vukovar: miejsca pamięci a dyskurs publiczny, w: Obóz - muzeum. Trauma we współczesnym wystawiennictwie, red. Małgorzata Fabiszak, Marcin Owsiński, Universitas, Kraków 2013, s. 193-214.

Feldman Andrea, Poslednjih tisuću godina: povijest žena - ženska povijest - kulturna povijest, „Otium” 1999-2000, nr 7-8, s. 30-37.

Feldman Andrea, Predgovor, w: Žene u Hrvatskoj. Ženska i kulturna povijest, red. Feldman Andrea, Institut „Vlado Gotovac”, Ženska infoteka, Zagreb 2004, s. 9-19.

Freidenreich Harriet, Yugoslavia, „Jewish Women's Archive” [online], https://jwa.org/encyclopedia/article/yugoslavia [dostęp: 28.02.2017].

Goldstein Slavko, Jasenovac - tragika, mitomanija, istina, Fraktura, Zaprešić 2016.

Hlevnjak Branka, Fotografkinje. Prilozi povijesti hrvatske fotografije 1870-2000., Društvo povjesničara umjetnosti Hrvatske Zagreb, Design Art, Zagreb 2005.

Hlevnjak Branka, Ivanuš Rhea, Hrvatska antiratna fotografija: Prvi svjetski, Drugi svjetski i Domovinski rat, Udruga za promicanje oblikovanja i umjetnosti, Design Art, Centar za kuluru i obrazovanje, Zagreb 2008.

Hudzik Agnieszka, Holokaust w obrazach fotograficznych, w: Teoria obrazu w naukach humanistycznych, red. Konrad Chmielecki, Beata Lisowska, Wydawnictwo Akademii Humanistyczno-Ekonomicznej, Łódź 2015, s. 105-114.

Ivanković Mladenka, The ,Sajmište” (Exhibition Grounds) in Semlin, Serbia: The Changing of Memory, „Jewish Political Studies Review”, t. 22 (2010), nr 3-4, s. 59-67. 
Ivanuš Rhea, Fotografije: Elvira Kohn. Retrospektiva, Galerija „Milan i Ivo Steiner”, Zagreb 1997. Iwasiów Inga, Twórczość niepozorna na barykadzie codzienności, w: Twórczość niepozorna. Szkice o literaturze, red. Joanna Grądziel-Wójcik, Agnieszka Kwiatkowska, Lucyna Marzec, Wydawnictwo Pasaże, Kraków 2015, s. 17-26.

Iwasiów Inga, Wstęp: Studia kobiece: między ,ja”, światem a literatura, w: Prywatne/publiczne. Gatunki pisarstwa kobiecego, red. Inga Iwasiów, Wydawnictwo Naukowe Uniwersytetu Szczecińskiego, Szczecin 2008, s. 7-11.

Jambrešić-Kirin Renata, Med iz Jasenovca, w: Jambrešić-Kirin Renata, Korice od kamfora, Meandarmedia, Zagreb 2015, s. 135.

Jambrešić-Kirin Renata, Prilozi za ratnu povijest iz rodne perspektive, „Otium” 1999-2000, nr 7-8, s. 75-86.

Jelavich Barbara, Historia Bałkanów. Wiek XX, przekł. Marek Chojnacki, Justyn Hunia, Wydawnictwo Uniwersytetu Jagiellońskiego, Kraków 2005.

Karge Heike, Sajmište, Jasenovac, and the Social Frames of Remembering and Forgetting, „Filozofija i društvo", 2012, nr 4, s. 106-118.

Katan Ben Zion Dina, The Feminine Voyage in the post Holocaust Jewish Literature in Former Yugoslavia, „Interkulturalnost” 2014, nr 7, s. 186-191.

Kečkemet Duško, Židovski sabirni logori na području pod talijanskom okupacijom, w: Antisemitizam, Holokaust, Antifašizam, red. Ivo Goldstein, Židovska općina Zagreb, Zagreb 1996, s. 120-132.

Knežević Đurđa, Žene u povijesti - historija bez žena, w: Seminar ,Žene i politika: žene u povijesti/historija bez žena”. Dokumentacija, red. Đurđa Knežević, Koraljka Dilić, Ženska infoteka, Zagreb 2001, s. 9-11.

Knežević Marija, Obóz jako metafora, przeł. Dorota Jovanka Ćirlić „Tygiel Kultury” 1997, nr 10-12, s. $15-18$.

Koch Magdalena, Kobiece narracje o Wielkiej Wojnie w serbskiej literaturze popularnej okresu międzywojennego (casus Milicy Jakovljević - Mir Jam), „Porównania” 2015, nr 16, s. 103-124.

Koljanin Milan, Nemački logor na Beogradskom Sajmištu 1941-1944, Institut za savremenu istoriju, Beograd 1992.

Kovačić Ivan, Kampor 1942-1943: Hrvati, Slovenci i Židovi u koncentracijskom logoru Kampor na otoku Rabu, Adamić, Rijeka 1998.

Leociak Jacek, Okaleczone obrazy. Uszkodzone fotografie (z) Zagłady jako wyzwanie interpretacyjne, w: Zagłada. Współczesne problemy rozumienia i przedstawiania, red. Przemysław Czapliński, Ewa Domańska, Poznańskie Studia Polonistyczne, Poznań 2009, s. 269-289.

Leociak Jacek, Tekst wobec Zagłady (o relacjach z getta warszawskiego), Fundacja na Rzecz Nauki Polskiej, Leopoldinum, Wrocław 1997.

Macdonald David Bruce, Balkan holocausts? Serbian and Croatian victim-centred propaganda and the war in Yugoslavia, Manchester University Press, Manchester and Chicago 2002.

Manojlović Pintar Olga, Ignjatović Aleksandar, Prostori selektovanih memorija: Staro sajmište u Beogradu i sećanje na Drugi svetski rat, w: Kultura sjećanja: 1941, red. Sulejman Bosto, Tihomir Cipek, Olivera Milosavljević, Disput, Zagreb 2008, s. 95-112.

Mataušić Nataša, Jasenovac 1941.-1945. Logor smrti i radni logor, Javna ustanova Spomen-područje Jasenovac, Naklada Jesenski i Turk, Jasenovac-Zagreb 2003.

Michałowska Marianna, Foto-teksty. Zwiąki fotografii z narracja, Wydawnictwo Naukowe UAM, Poznań 2012. 
Михаиловић Драгослав, На трагу гулага и холокауста, w: tegoż, Кратка историја сатирања, Завод за уџбенике и наставна средства, Београд 2005, s. 79-82.

Peić Čaldarović Dubravka, „Ženska posla” između obitelji i profesije, „Otium” 1999-2000, nr 7-8, s. 66-74.

Pollack Martin, Skażone krajobrazy, przekł. Karolina Niedenthal, Wydawnictwo Czarne, Wołowiec 2014.

Preserving Jewish memory - Bringing history to life: Elvira Kohn, 2003 [online], http://www. centropa.org/biography/elvira-kohn [dostęp: 28.02.2017].

Prlenda Sandra, Ženska povijest i sjećanje na Drugi svjetski rat, w: Sjećanja žena žrtava nacizma i nedemokratskih režima, red. Sandra Prlenda, Centar za ženske studije, Zagreb 2009, s. 11-18.

Program Pressing (Milan Ristović, Bojan Dimitrijević), 8.12.2015 [online], https://www.youtube. com/watch?v=jjT3GFYfh4M [dostęp: 28.02.2017].

Rumenjak Natalija, Povijest žena u hrvatskoj historiografiji, „Otium” 1999-2000, nr 7-8, s. 27-29.

Šarenac Danilo, Pantelić Ivana, Dve polovine sećanja. Partizanski dnevnici kao izvor za istoriju Drugog svetskog rata, Institut za savremenu istoriju, Beograd 2013.

Semlin Juenlager [online], http://www.semlin.info/ [dostęp: 28.02.2017].

Sobolevski Mihael, Dnevnik Milojke Mezorane - sušačke Anne Frank, „Sveti Vid” 2006, nr 11, s. $151-188$.

Spomen područje Jasenovac [online], www.jusp-jasenovac.hr/Default.aspx?sid=5021 [dostęp: 28.02.2017].

Struk Janina, Holokaust w fotografiach. Interpretacje dowodów, przekł. Maciej Antosiewicz, Prószyński i S-ka, Warszawa 2007.

Strzelczyk Jerzy, Pióro w wątych dtoniach. O twórczości kobiet w wiekach dawnych, t. 1-2, Wydawnictwo DiG, Warszawa 2007-2009.

Taczyńska Katarzyna, „A Scattered Mosaic of Records and Reminiscences”: Ženi Lebl's War Odyssey in Her Personal Writings, w: An Introspective Approach to Women's Intercultural Fieldwork, red. Urszula Markowska-Manista, Justyna Pilarska Justyna, Wydawnictwo Akademii Pedagogiki Specjalnej im. M. Grzegorzewskiej, Warszawa 2017, s. 68-102.

Taczyńska Katarzyna, ,Dowcip trwajacy dwa i pót roku”. Obraz Nagiej Wyspy w serbskim dyskursie literackim i historycznym końca XX i poczatku XXI wieku, Wydawnictwo DiG, Edition La Rama, Warszawa-Bellerive-sur-Allier 2016.

Taczyńska Katarzyna, Pamięć matki - pamięć o matce. O „Dzienniku pewnej Judyty” Ženi Lebl, „Miscellanea Posttotalitariana Wratislaviensia” 2017, nr 6: Trauma jako kulturowy palimpsest: (post)komunizm w kontekście porównawczym nowoczesności, totalitaryzmów i (post)kolonializmów, red. Dorota Kołodziejczyk, Bogdan Stefanescu, Mateusz Świetlicki, s. 217-231.

The Righteous Among The Nations: Ercegović Family, Yad Vashem [online], http://db.yadvashem. org/righteous/family.html?language=en\&itemId=4042602 [dostęp: 28.02.2017].

Twardowska Aleksandra, La mužer sefardi de Bosna. Literacka i kulturalna działalność Laury Papo-Bohorety, w: Poznać Bałkany. Historia - Polityka - Kultura, red. Katarzyna Taczyńska, Szymon Sochacki, Miloš Zečević, Interdyscyplinarne Koło Naukowe Doktorantów, Toruń 2011, s. 205-213.

Twórczość niepozorna. Szkice o literaturze, red. Joanna Grądziel-Wójcik, Agnieszka Kwiatkowska, Lucyna Marzec, Wydawnictwo Pasaże, Kraków 2015.

Ubertowska Aleksandra, „Niewidzialne świadectwa”. Perspektywa feministyczna w badaniach nad literatura Holokaustu, „Teksty Drugie” 2009, nr 4, s. 214-226. 
Večerina Tomaić Jagoda, Bohoreta - najstarija kći, Židovska vjerska zajednica Bet Israel, Zagreb 2016.

Zacharias Michał Jerzy, Polityka KPJ i kwestia narodowościowa w Jugosławii w latach 1919-1943, „Studia z Dziejów Rosji i Europy Środkowo-Wschodniej”, t. 39 (2004), s. 27-59.

Zanimljive žene: Elvira Kohn, „Makabijada” [online], http://www.makabijada.com/dopis/elvirakon.htm [dostęp 28.02.2017].

Ženski logor na Golom otoku. Ispovesti kažnjenica i islednice, red. Dragoslav Simić, Boško Trifunović, ABC Product, Beograd 1990.

Katarzyna Taczyńska

\section{And where now? The issue of concentration camps in Yugoslav perspective:} the case of Elvira Kohn

\section{Summary}

The text contains an analysis of photographs and personal (written) documents by Elvira Kohn (1914-2003), a Jew and a female prisoner of Kampor concentration camp, established in July 1942 on Rab island in Croatia. The article explores the specific features of a narrative about World War II and the Jewish experience in Yugoslavia which emerge from the materials. Presented so that they complement each other, photographs understood as photo-texts (Marianna Michałowska) and a diary and a poem recognized as inconspicuous texts (Jerzy Strzelczyk, Inga Iwasiów) form Kohn's personal narrative. The microhistory (Ewa Domańska) of this photographer and writer is presented as material supplementing the knowledge about the past of Jews in Yugoslavia, which - due to the choices Elvira Kohn made in her life and art - can also be considered as evidence of emancipatory social changes of that period, and as an example of overcoming the existing cultural paradigms.

Keywords: Yugoslavia; Rab Concentration Camp; Jewish history; photo-text; inconspicuous text; personal narrative; microhistory 